\title{
Комплексирование георадиолокационных исследований грунтов криолитозоны
}

Омельяненко П.А., Институт мерзлотоведения им. П.И. Мельникова СО РАН, 2. Якутск, E-mail: omepavel@yandex.ru

В целях повышения эффективности георадиолокационных исследований грунтов криолитозоны разработана комплексная методика рекогносцировочных работ, профилирований, зондирований.

Методика рекогносцировочных работ включает измерения диэлектрической проницаемости, электропроводности почвенного слоя и удельного электрического сопротивления сезонно-протаявшего слоя. Методика основана на принципе параметрических измерений электромагнитного поля. Обоснована возможность оценки криогенного состояния грунта посредством дистанционного определения количества незамерзшей влаги. Выбраны параметры измерений, обладающие повышенной чувствительностью к фазовому переходу лед-вода. В качестве индикаторов использованы приборы, допускающие работу с выносными датчиками, что расширяет область применения разработанной методики в полевых условиях. В перспективе, разработка новых датчиков контактного и погружного типов позволит косвенно определять на качественном уровне физико-механические свойства грунтов естественного залегания на заданной глубине и открывается возможность дистанционного изучения миграции влаги в процессе промерзания - протаивания грунта.

Разработанный методический комплекс, дополнительно включает профилирования и методом двухспектральной георадиолокации и зондирования в точках опорных наблюдений, для детального исследования строения и состояния геокриологического разреза одновременно в двух перекрывающихся диапазонах глубин. В точках опорных наблюдений, для повышения достоверности и увеличения точности измерений, проводят бурение заверочных скважин. При интерпретации в качестве опорных геокриологических данных принимают литологический разрез полученный по скважинам пробуренным с отбором и анализом керна.

В результате, разработанный комплексный методический подход позволяет получать достаточно полную информацию о сложном геокриологическом разрезе.

Экспериментально установлено, что для повышения эффективности инженерногеокриологических исследований особенно в условиях урбанизированных территорий целесообразно комплексирование георадиолокационных методов с методами электрометрии на стадиях рекогносцировочных работ.

Работа выполнена при поддержке гранта РФФИ 15-45-05050 